\title{
THE IMPACTS OF MEDICAL CAREER DAY TO MEDICAL STUDENTS' INTEREST TO PURSUE A CAREER IN PUBLIC HEALTH
}

\author{
Rio Yus Ramadhani*, Rizma Adlia Syakurah**, Mariatul Fadilah** \\ * Undergraduate Medical Student, Faculty of Medicine, Universitas Sriwijaya - Indonesia \\ ** Department of Public Health, Universitas Sriwijaya - Indonesia
}

\begin{abstract}
Background: Medical career day is one of the activities to introduce career options that exist and increase interest in a particular career. This study aims to determine the effect of material medical career day activities to increase the interest of medical students to pursue a career to the field of public health sciences.

Method: This study is a quasi-experimental study with pretest-posttest control group design. The control group received counseling about the field of public health sciences, whereas the intervention group receive the same counseling accompanied by a description of the activity-based cost and opportunity cost in the field of public health sciences. The study population was 216 students of medical faculty batch 2014. Out of 216 students, 70 met the inclusion criteria, and only 36 who came to the activity. Data analysis was performed using paired t-test.

Results: Thirty-six students came to the medical career day activities are divided into 2 groups: the first 18 people who come into the intervention group and 18 others to a control group. Increased interest in the control group ( $\mathrm{p}=0.003)$ and increased interest in the intervention group was also significant $(\mathrm{p}=0.023)$.

Conclusion: Material medical career day activities plus activity based cost and opportunity cost may increase the interest of students to pursue a career to the field of public health sciences.
\end{abstract}

Keywords: medical career day, student's interest, public health

\section{ABSTRAK}

Latar belakang: Medical career day sebagai salah satu kegiatan untuk memperkenalkan pilihan karir yang ada dan meningkatkan minat pada karir tertentu. Penelitian ini bertujuan untuk mengetahui pengaruh materi kegiatan medical career day untuk meningkatkan minat mahasiswa kedokteran untuk melanjutkan karir ke bidang ilmu kesehatan masyarakat.

Metode: Penelitian ini adalah penelitian kuasi eksperimental dengan rancangan pretest-posttest with control group design. Kelompok kontrol mendapat penyuluhan mengenai bidang ilmu kesehatan masyarakat, sedangkan kelompok intervensi mendapatkan penyuluhan yang sama disertai penjelasan mengenai activity based cost dan opportunity cost di bidang ilmu kesehatan masyarakat. Populasi penelitian adalah mahasiswa. Program Studi Pendidikan Dokter angkatan 2014, sejumlah 216 orang. Dari jumlah tersebut 70 memenuhi kriteria inklusi, dan dari 70 orang tersebut hanya 36 yang datang ke kegiatan. Tiga puluh enam orang tersebut menjadi sampel penelitian. Analisis data dilakukan dengan uji paired t-test.

Hasil: Tiga puluh enam orang mahasiswa datang ke kegiatan medical career day dibagi 2 kelompok yaitu 18 orang pertama yang datang menjadi kelompok intervensi dan 18 orang lainnya menjadi kelompok kontrol. Peningkatan minat pada kelompok kontrol bermakna ( $p=0.003)$ dan peningkatan minat pada kelompok intervensi juga bermakna $(p=0.023)$. Kesimpulan: Materi kegiatan medical career day yang ditambah activity based cost dan opportunity cost dapat meningkatkan minat mahasiswa untuk melanjutkan karir ke bidang ilmu kesehatan masyarakat.

Kata kunci: medical career day, minat mahasiswa, ilmu kesehatan masyarakat

Contact: husna_imanda@yahoo.co.id 


\section{INTRODUCTION}

Indonesia, a country with more than 250 million population, has a big challenge in delivering health service. Therefore, the fund needed to treat the sick population is not little. On the other hand, that certain fund could have been reduced if public awareness about health were higher.

Because of that, Indonesia established a program called Jaminan Kesehatan Nasional (JKN) or "National Health Security" to overcome financial problem in lower income population by a subsidy from higher income population. This program is then organized by Badan Penyelenggara Jaminan Sosial (BPJS) or "Social Security Organizer". ${ }^{1}$ Gradually, this program will cover the whole society. ${ }^{2}$

In choosing a career, students often feel confused because of the little knowledge they have about career options. This condition hampers career development. Career day is an activity to help students understand the working world and to reduce nervousness and stress in choosing a career. $98 \%$ of the correspondents in a study about the benefits of a career day expressed that this activity was useful and was a valuable experience for them. They also claimed that a career day gave a deeper understanding towards residency options. ${ }^{3}$

Based on the facts above, we conducted a study to know if a career day might attract students to develop a career specifically in public health, so that the number of health care providers in public health may increase and may improve health in Indonesia.

\section{METHODS}

This was a quasi-experiment using pretest-posttest method with separate samples. This study was performed in the Medical School of Faculty of Medicine, Universitas Sriwijaya from November 2014 until January 2015. The study population was the entire class of 2014 medical students of Faculty of Medicine, Universitas Sriwijaya. The samples were all of students who fulfilled the inclusion criteria. The inclusion criteria were:

- class of 2014 medical students

- had an interest score of 1-7 in the pretest

- consented to be a study subject
The samples needed for the experiment were 30 students. Samples were chosen randomly (random sampling) from three classes: Alpha, Beta, and Gamma of the class of 2014 who fulfilled the inclusion criteria until the number of samples needed was met. Samples were then divided into an intervention group and a control group. The intervention group was given lectures about activity-based cost and opportunity cost in public health. Meanwhile, the control group was given a lecture about public health only. Activity-based cost explained the cost needed to study public health and compared that cost to the cost needed to study other medical field. Opportunity cost explained the benefits of pursuing a career in public health.

The independent variable in this study was medical career day. The dependent variable was students' interest to pursue a career in public health. The parameter of the success of this study was the increase of students' interest to pursue a career in public health after participating in medical career day.

The data used in this study was primary data, obtained directly from the respondents using a questionnaire. The questionnaire answers obtained from the pretest and the posttest were then examined, validated, coded, recapitulated, and tabulated. After the data was processed, the data using likert scale was analyzed with paired t-test where $p<0.05$ was considered significant and independent t-test where $p<0.05$ was considered significant using SPSS ver 16.0, then the results were presented in tables. Meanwhile, data from written answers was analyzed and presented narratively and in tables. Data was analyzed by comparing questionnaires results from the pretest to the results from the posttest.

\section{RESULTS AND DISCUSSION}

This study was a quasi-experiment with pretestposttest method using control group design. Study subjects were obtained from distributing pretest questionnaire to 200 class of 2014 medical students of Faculty of Medicine, Universitas Sriwijaya, which in total the number of the students was 216. Only 112 students consented to be a subject in the pretest and the rest did not answer or return the distributed questionnaires. From the pretest questionnaire, 70 
students fulfilled the inclusion criteria. From the 70 students who fulfilled the inclusion criteria, only 36 students consented to participate in medical career day. Those 36 students were divided into two groups, 18 students who came first were put in the intervention group and the rest were put in the control group.

The control group received a lecture about basic introduction to public health and the professions in public health. Meanwhile, the intervention group received the same lecture about basic introduction to public health and the professions, added with lectures from interviewees from public health department to tell their experiences while pursuing careers in public health. Aside from that, those students also received information about activity-based cost, the cost needed to study public health, and compared that cost to the cost needed to study other medical field. They also received information about opportunity cost, the benefits obtained while pursuing careers in public health.
Based on the pretest questions about the careers known by class of 2014 medical students of Faculty of Medicine, Universitas Sriwijaya, respondents had already been able to answer more than one professions as career options in public health after graduating medical school. Those career options varied and were presented in Diagram 1.

Based on that diagram, the careers mentioned mostly by students was general practitioner, specialist doctor, lecturer, researcher, and others. There were also some careers mentioned by students, but do not fall into medical careers, namely psychologist, nurse, and dentist. Few students also mentioned a career as hospital manager and minister of health.

The other category in Diagram 1 included career options mentioned by respondents, but not more than ten respondents mentioned those careers, namely primary care doctor, structural doctor, head of primary health care center, and other careers that are seldom pursued after graduating medical school.

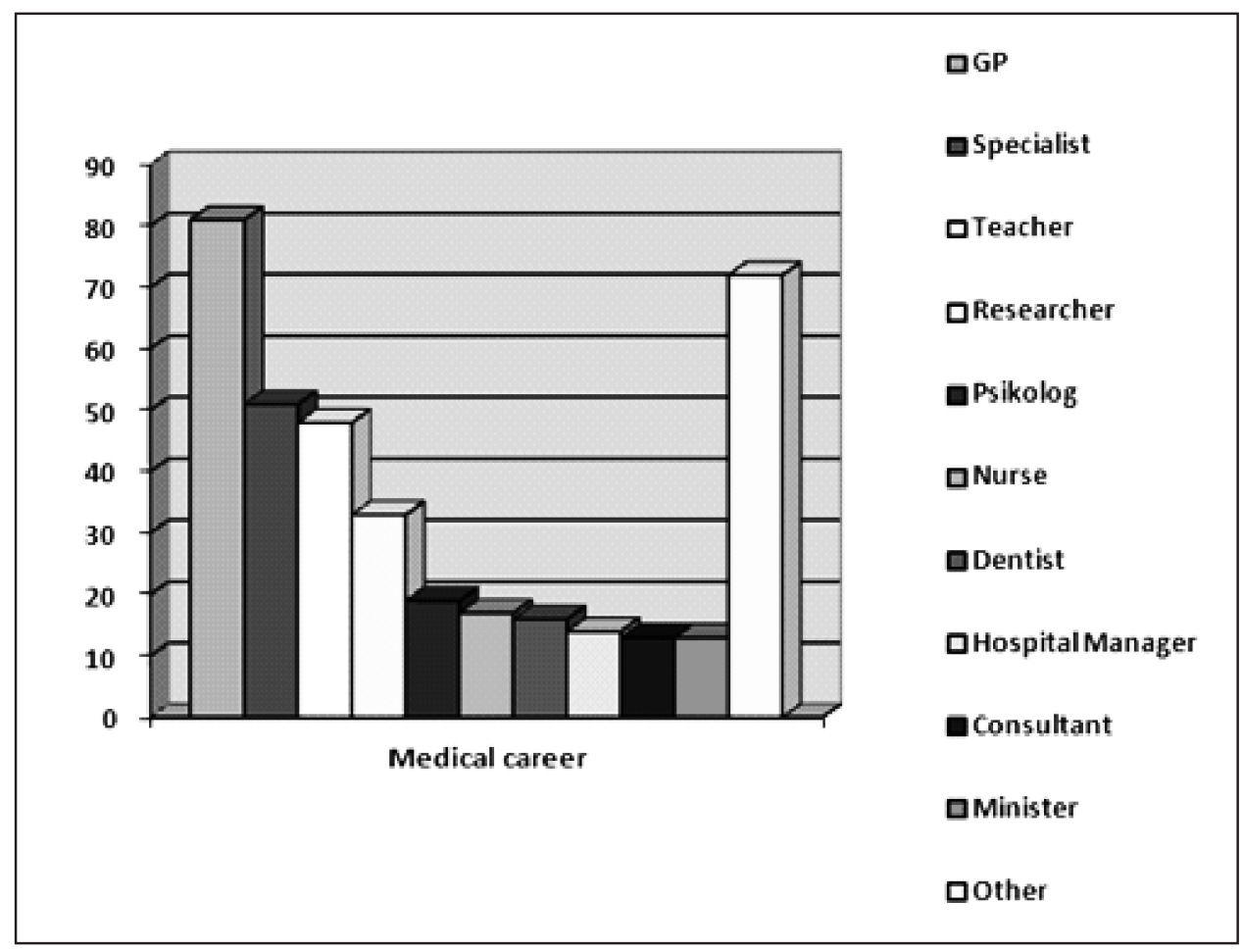

Diagram 1. Known medical careers 
Based on the pretest question about the sources where class of 2014 medical students of Faculty of Medicine, Universitas Sriwijaya obtained career options information from, in which we provided multiple choices of parents, society, printed media, and electronic media, as well as others that might contribute as information sources of career options, most of the students did not answer by ticking only one choice, even many respondents answered by ticking all of the choices. Some also mentioned other sources such as lectures and other activities. The results are presented in Diagram 2.

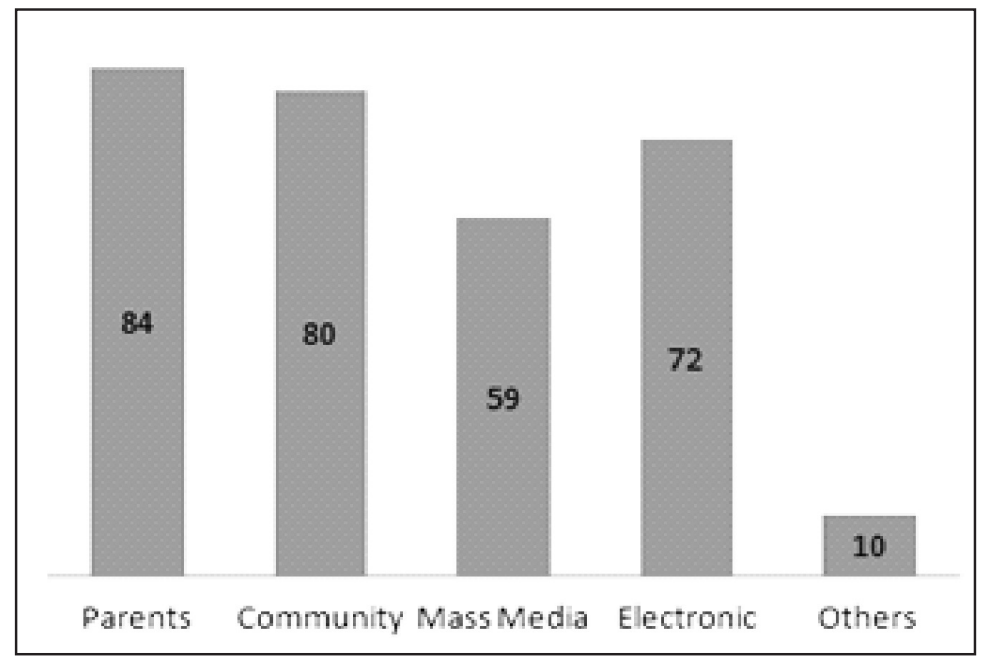

Diagram 2. Sources of students' career information

According to Diagram 2, respondents answered that parents were the main source for students to obtain the kinds of careers to pursue after graduating medical school. However, other choices were also mentioned aside from parents. Printed media was the least mentioned source.

Homogeneity test was performed to know the homogeneity between the two groups. This test was required for quasi-experimental study. This test was performed by inputting pretest interest scores from the two groups into SPSS ver 16.0 using One-Way ANOVA. In the output results in Table $1, p$ of 0.89 was obtained. With $p>0.05$, it was concluded that the variance in each group was homogeneous. It meant that quasi-experimental method could be implemented in this study

Table 1. Homogeneity test

\begin{tabular}{|c|c|c|c|c|c|}
\hline \multirow{3}{*}{ Variables } & \multirow{2}{*}{\multicolumn{2}{|c|}{$\begin{array}{c}\text { Intervention } \\
\text { Pretest }\end{array}$}} & \multirow{2}{*}{\multicolumn{2}{|c|}{$\begin{array}{c}\text { Comparison } \\
\text { Pretest }\end{array}$}} & \multirow{3}{*}{$\mathrm{P}^{*}$} \\
\hline & & & & & \\
\hline & $\mathrm{n}$ & $\%$ & $\mathrm{n}$ & $\%$ & \\
\hline \multicolumn{6}{|l|}{ Passion } \\
\hline 1 & 1 & 5,6 & 1 & 5,6 & \multirow[t]{8}{*}{0,89} \\
\hline 3 & 2 & 11,1 & 2 & 11,1 & \\
\hline 4 & 1 & 5,6 & 2 & 11,1 & \\
\hline 5 & 5 & 27,7 & 3 & 16,7 & \\
\hline 6 & 2 & 11,1 & 4 & 22,2 & \\
\hline 7 & 6 & 33,3 & 5 & 27,7 & \\
\hline 9 & 1 & 5,6 & 0 & 0 & \\
\hline 10 & 0 & 0 & 1 & 5,6 & \\
\hline
\end{tabular}


Data analysis of pretest and posttest interest scores of the intervention group was performed to know the comparison of interest scores in this group before and after the activity. This test was done by inputting pretest and posttest interest scores into SPSS ver 16.0 using paired t-test.

In Table 2, it is shown that $p=0.023$. It can be concluded that medical career day given to the intervention group was significant, which means that there was a significant increase of interest to pursue a career in public health after the activity was held.

Data analysis of pretest and posttest interest scores of the control group was performed to know the comparison of interest scores in this group before and after the activity. This test was performed by inputting pretest and posttest interest scores of the control group into SPSS ver 16.0 using paired t-test.

Table 2. Data analysis of pretest and posttest scores in the intervention group

\begin{tabular}{|c|c|c|c|c|c|}
\hline \multirow{3}{*}{ Variable } & \multicolumn{4}{|c|}{ Intervention } & \multirow{3}{*}{$\mathrm{P}^{*}$} \\
\hline & \multicolumn{2}{|c|}{ Pretest } & \multicolumn{2}{|c|}{ Posttest } & \\
\hline & $\mathrm{n}$ & $\%$ & $\mathrm{n}$ & $\%$ & \\
\hline \multicolumn{6}{|l|}{ Passion } \\
\hline 1 & 1 & 5,6 & 0 & 0 & \multirow[t]{8}{*}{0,023} \\
\hline 3 & 2 & 11,1 & 0 & 0 & \\
\hline 4 & 1 & 5,6 & 1 & 5,6 & \\
\hline 5 & 5 & 27,7 & 2 & 11,1 & \\
\hline 6 & 2 & 11,1 & 2 & 11,1 & \\
\hline 7 & 6 & 33,3 & 10 & 55,5 & \\
\hline 8 & 0 & 0 & 2 & 11,1 & \\
\hline 9 & 1 & 5,6 & 1 & 5,6 & \\
\hline
\end{tabular}

In Table 3 , it is shown that $p=0.003$. It can be concluded that medical career day given to the control group was significant, which means that there was a significant increase of interest to pursue a career in public health after the activity was held.

Table 3. Data analysis of pretest and posttest scores in the control group

\begin{tabular}{|c|c|c|c|c|c|}
\hline \multirow{3}{*}{ Variables } & \multicolumn{4}{|c|}{ Comparison } & \multirow{3}{*}{$\mathrm{P}^{*}$} \\
\hline & \multicolumn{2}{|c|}{ Pretest } & \multicolumn{2}{|c|}{ Posttest } & \\
\hline & $\mathrm{n}$ & $\%$ & $\mathrm{~N}$ & $\%$ & \\
\hline \multicolumn{6}{|l|}{ Passion } \\
\hline 1 & 1 & 5,6 & 0 & 0 & \multirow[t]{9}{*}{0,003} \\
\hline 3 & 2 & 11,1 & 0 & 0 & \\
\hline 4 & 2 & 11,1 & 2 & 11,1 & \\
\hline 5 & 3 & 16,7 & 2 & 11,1 & \\
\hline 6 & 4 & 22,2 & 4 & 22,2 & \\
\hline 7 & 5 & 27,7 & 5 & 27,7 & \\
\hline 8 & 0 & 0 & 3 & 16,7 & \\
\hline 9 & 0 & 0 & 2 & 11,1 & \\
\hline 10 & 1 & 5,6 & 0 & 0 & \\
\hline
\end{tabular}


Data analysis of medical career day satisfaction scores in the intervention and control group was performed to know the comparison of medical career day satisfaction scores between both groups after the activity was held. This test was performed by inputting medical career day satisfaction scores of the intervention and control group into SPSS ver 16.0 using unpaired t-test (shown in table 4).

Table 4. Comparison of posttest scores between intervention and control group

\begin{tabular}{cccccc} 
& \multicolumn{2}{c}{ Intervention } & \multicolumn{2}{c}{ Comparison } \\
Variables & \multicolumn{2}{c}{ Posttest } & \multicolumn{2}{c}{ Posttest } & $\mathrm{P}^{*}$ \\
& $\mathrm{~N}$ & $\%$ & $\mathrm{n}$ & $\%$ & \\
\hline Passion & & & & & \\
4 & 1 & 5,6 & 2 & 11,1 & 0,806 \\
5 & 2 & 11,1 & 2 & 11,1 & \\
6 & 2 & 11,1 & 4 & 22,2 & \\
7 & 10 & 55,5 & 5 & 27,7 & \\
8 & 2 & 11,1 & 3 & 16,7 & \\
9 & 1 & 5,6 & 2 & 11,1 & \\
\hline Total & 18 & \multicolumn{5}{l}{18} \\
\hline
\end{tabular}

In Table 5 , it is shown that $p=0.531$. It means that satisfaction scores between the intervention and control group did not differ significantly, which means that both groups were satisfied with medical career day activity.

Table 5. Comparison of medical career day satisfaction in intervention and control group

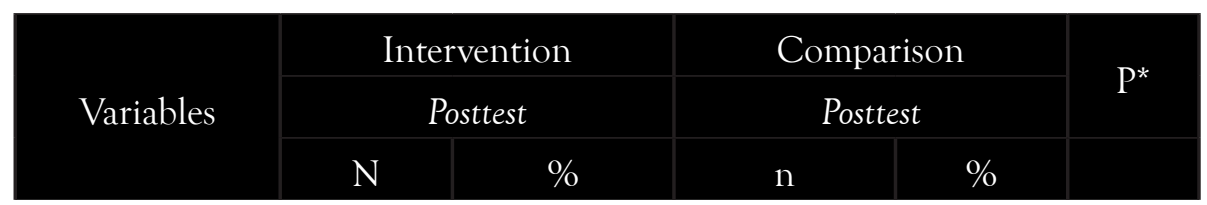

\begin{tabular}{cccccc} 
Passion & & & & & \\
4 & 0 & 0 & 2 & 11,1 & 0,531 \\
6 & 3 & 16,7 & 3 & 16,7 & \\
7 & 6 & 33,3 & 5 & 27,8 & \\
8 & 8 & 44,4 & 5 & 27,8 & \\
9 & 0 & 0 & 2 & 11,1 & \\
10 & 1 & 5,6 & 1 & 5,6 & \\
\hline Total & 18 & & 18 & \\
\hline
\end{tabular}


Table 6 presents the change of career choices of medical career day participants in the intervention group before and after the activity. Some students did not change their career choices, but some did, even changed them to careers in public health.

Table 6. Comparison of career options in the intervention group

\begin{tabular}{ll}
\hline Pretest & Posttest \\
GP & Specialist \\
Specialist & Specialist \\
Specialist & Public health \\
Specialist & Public Health \\
Specialist, entrepreneur & Specialist \\
GP & Specialist, entrepreneur \\
- & Specialist \\
Specialist, teacher & Specialist \\
GP & Specialist \\
Specialist & Specialist, GP, researcher \\
Specialist & Specialist \\
Specialist & Specialist, public health \\
Specialist & Hospital manager \\
GP, teacher & Hospital manager \\
Specialist & Teacher, public health \\
Specialist & Specialist, public health \\
Specialist & Specialist, GP \\
\hline
\end{tabular}

Table 7 shows the change of career choices of medical career day participants in the control group before and after the activity. Some students did not change their career choices, but some did, even changed them to careers in public health. 
Table 7. Comparison of career options in the control group

\begin{tabular}{ll} 
Pretest & Posttest \\
\hline Structural & Structural \\
Specialist & Specialist, DLP, military doctor \\
Specialist & Specialist \\
Specialist & Specialist \\
- & Specialist \\
Researcher & Researcher \\
Specialist & Specialist \\
Specialist & Specialist \\
Specialist & Specialist \\
Specialist & Specialist \\
Specialist & Specialist \\
Specialist & Specialist \\
- & Specialist \\
Specialist & Specialist, Public health \\
GP & Specialist \\
Specialist & GP, teacher \\
GP, teacher & Specialist \\
Specialist & \\
\hline
\end{tabular}

Class of 2014 medical students of Faculty of Medicine, Universitas Sriwijaya that were involved in the pretest had already known a few career options in medicine to pursue after graduating medical school. In fact, students were already able to answer more than one career options. Unfortunately, from these career options, students still did not know about career options in public health. This showed that career options in public health were not wellknown by class of 2014 medical students of Faculty of Medicine, Universitas Sriwijaya. Although career options in public health were not so well-known, there were few students who had already been able to answer some career options that were closely related to public health, such as hospital manager and the minister of health. This showed that health management and administration in public health had already been known by students as one of the career options in medicine.

Those career options were discovered by students through various information sources. There were many information sources, but from all those sources, students had still not known about careers in public health. Necessarily, those information sources could be used as much as possible, considering now is an era where electronic media are often used to search for information. Not just electronic media, other media also need to be used to spread information about career choices in public health so that students might be interested to choose a career in public health.

Medical career day which was held for class of 2014 medical students of Faculty of Medicine, Universitas Sriwijaya gave significant results in both intervention and control group. The increase of interest scores after the activity showed that medical career day could influence students in choosing a career. Medical career day delivered new information to those students, especially about career options in public health. This corresponds well with a study by White ${ }^{3}$ that claimed that medical career day gave significant results in choosing a career. Consequently, this medical career day could be held periodically so that the number of students who get interested to pursue a career in public health might increase. 
Medical career day with lectures only or with additional lectures about activity-based cost and opportunity cost did not give different results. Interest increase, either in intervention group or control group, seemed the same although the activities were different. This means that lectures only were able to increase students' interest and knowledge to pursue a career in public health. This might be because of some factors, either factors from the activity itself or from the students. Factors from the activity might be from the interviewees, duration, or technical stuff. Factors from the students might be from the students themselves, such as playing with their own stuff, coming late, etc.

In the results, it was found that many of the intervention group students started to consider public health as a second choice of career after medical career day activity. This corresponds well with many students who chose public health as a second choice or because it was not their passion. ${ }^{4}$ After all, passion or interest is needed as a motivation to do a job. ${ }^{5}$ Interest increase in this intervention group was caused by the increase of knowledge in medical career day participants about public health. Students in the control group did not have their interest increased to choose a career in public health after graduating medical school. This means that medical career day increases students' interest.

There were a few things affecting the results of this study. Limited amount of time the interviewees had and it still needed to be adjusted to the date of the career day; how the interviewees delivered the material; problem in the participants, such as incomplete filling of the questionnaire or did not fill the questionnaire at all; bias answers in the questionnaire which might affect the results; had other appointment during medical career day which decrease the number of students who participated in the activity. Those limitations caused medical career day did not run optimally and needed to be held on a different day. Medical career day in the intervention group were held on a Saturday and it means that students who were present could be considered to have high intentions to actually receive knowledge from medical career day. Medical career day for the control group were held in the afternoon after class and the students were not serious enough to fill in the questionnaire.
Career day should be held for more than a day and is not similar to the one in this study and it made the impact were not as big as it should be because a few students complains of the little information they received. They also thought that interviewees should be someone from outside of their campus, better yet someone who they never met before.

The mistakes and limitations that might happen during the study might affect the results of the impact of medical career day to students' interest to pursue a career in public health in medical students of Faculty of Medicine, Universitas Sriwijaya.

\section{CONCLUSIONS}

According to the results and discussion above about the impact of medical career day to students' interest to pursue a career in public health, it can be concluded that medical career day increases students' interest to pursue a career in public health. Furthermore, interest increase in the intervention and control group did not differ significantly, but many of the students in the intervention group were interested to choose a career in public health.

\section{REFERENCES}

1. Republik Indonesia. Undang-Undang No. 40 Tahun 2004 tentang Sistem Jaminan Sosial Nasional. Lembaran Negara RI Tahun 2004, No. 150. Jakarta: Sekretariat Negara; 2004.

2. Republik Indonesia. Undang-Undang No. 24 Tahun 2011 tentang Badan Penyelengara Jaminan Sosial. Jakarta: Sekretariat Negara; 2011.

3. White BM, Meyer TL, Navuluri ND. "Career Days" to Increase Exposure to Careers in Medicine During the Preclinical Years. Poster of Research in Medical Education no.78 Association of American Medical Colleges 2012.

4. Kumar R, Singh A, Gupta SN. Public health as a career option: postgraduate students' perspective. Indian Journal of Preventive Medicine 1, 2013(1):29-34.

5. Hurlock EB. Perkembangan Anak. Jakarta: Erlangga; 1999. 